\title{
Academic Library Directors: A Managerial Role Profile
}

\author{
Terrence F. Mech
}

Using Mintzberg's managerial role typology, this study examines the managerial profile of 354 academic library directors. Survey results indicate directors are active primarily with internal managerial roles. However, there are significant differences among the managerial profiles of directors at doctoral, comprehensive, baccalaureate, and two-year institutions. Directors also report their work contacts and rate the importance of human, conceptual, political, and technical skills to their work.

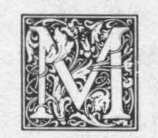

any librarians view a library directorship as the pinnacle of a natural career progression. Within the library, the director is at the top of a pyramid and has certain responsibilities toward the library. However, within the larger academic organization, the library director is only a middle manager having responsibilities toward the larger organization.

Because library directors seldom move up or laterally into other administrative positions within the larger academic organization, some view their position as a dead-end job. ${ }^{2}$ While organizational and attitudinal barriers may restrict library directors' upward mobility, the managerial roles library directors emphasize may also restrict their ability to obtain the necessary power and required influence for upward mobility within the larger academic organization.

A number of phenomena shape a director's managerial role profile. Like most academic managers, library directors receive little structured preparation for their managerial roles. They "learn the ropes" on their own. Within the library, managerial acculturation is not easy, since it takes place within a professional organizational context in which there are conflicting professional and managerial views, values, and norms. Successful library directors make the transition from practicing librarians to library managers. They learn to make compromises and to tolerate uncertainty. Some librarians make that transition successfully and develop a commitment to management and their managerial roles. Others reject their managerial roles in favor of their professional roles, while others are unsure of their managerial commitment and their willingness to perform the roles of managers. ${ }^{3}$

Academic institutions are highly decentralized organizations that rely on the skill of their professionals to perform the organization's primary functions. ${ }^{4}$ Emphasizing professional expertise rather than the power of the office, middle management structures in academic organizations are thin and not very elaborate. Middle managers work in parallel administrative structures, one democratic and bottom-up for professionals, and a second, hierarchical and top-down for support staff. Academic middle managers must also work alongside a faculty committee structure. Coordination problems arise frequently among the parallel structures. Because the various administrative structures rely on mutual adjustment for coordination, liaison functions are important for academic middle managers. Academic middle man- 
agers spend much time handling jurisdictional disputes and other structural disturbances. $^{5}$

Middle managers serve key roles at the boundaries of their organizations, between professionals on the inside and interested parties on the outside. Drawn from the professional ranks, middle managers are expected to protect the professionals' autonomy and "buffer" them from external pressure while simultaneously seeking outside support for the organization. Caught in various tugs-ofwar, middle managers (errand runners of the professionals or "lackeys" of the administration) keep their influence only as long as they are perceived as serving the interests of their various constituencies. ${ }^{6}$

\section{"Library directors receive little struc- tured preparation for their manage- rial roles."}

In examining their managerial roles, library directors must consider the nature of their institution's work, how their institution goes about it, and their institution's external environment. Differences in these elements lead to differences in organizational management systems. Organizations and their managers seek management structures and behaviors that most effectively support their organizations' work. ${ }^{7}$

\section{LITERATURE REVIEW}

Since the mid-1970s, investigators have examined the managerial orientations of academic library directors. Utilizing role theory, Susan Lee postulates that the work of library directors is an array of roles performed in their organizations. ${ }^{8}$ Associated with their positions is a set of activities or potential behaviors that constitute the roles to be performed by any individual who occupies that position. Role expectations for library directors also exist in the minds of others. These expectations represent the standard by which others evaluate a director's performance. ${ }^{9} \mathrm{Nu}$ merous conflicting expectations shape the director's role. While most directors "acknowledge the importance of their role as ambassador for the library," they also feel they are "walking a thin line between the external demands of their positions and the in-house needs of their personnel. ${ }^{\prime 10}$

While library directors concentrate their energy on internal library matters, they "realize the importance of their efforts beyond the walls of their own organizations, but they are not always able to fill this ideal role and simultaneously accommodate internal pressures."'11 Paul Metz found that structural and environmental factors shape the director's role. Personal variables (gender, age, and education) have little influence on the director's role performance. "Directors at larger, more complex institutions are more heavily involved with environmental issues and deal less extensively with internal library matters than do their counterparts in small college libraries." 12

Henry Mintzberg's managerial role model is frequently used to describe the managerial roles of library directors. ${ }^{13}$ Paul J. Pugliese found that directors of large academic and public libraries rate their managerial roles similarly. Academic directors give their internal and external roles very similar scores. ${ }^{14}$ Among middle managers in large academic and public libraries, public library middle managers are more active with their internal roles while academic middle managers are more active with their external roles. ${ }^{15}$ Another study finds library directors at medium-sized public libraries favoring their internal roles. $^{16}$

\section{"Internal groups (library middle managers) and external groups (dean-level colleagues) tend to evalu- ate the library director's performance differently."}

Joanne R. Euster's study of the academic library director's role in influencing the library's external environment gathered information on directors, their mid- 
dle managers, and deans. ${ }^{17}$ Using Morgan W. McCall and Cheryl A. Segrist's operational scales of Mintzberg's model, ${ }^{18}$ directors report similar average external and internal role scores. ${ }^{19}$ Internal groups (library middle managers) and external groups (dean-level colleagues) tend to evaluate the library director's performance differently. While dean-level colleagues rate directors' performances of every role higher than do the directors' middle managers, middle managers' rating of their directors closely match directors' perceptions of their own role performance. Euster speculates "dean-level colleagues outside the library evaluate more impressionistically, basing their conclusions on overall perceptions of the effectiveness of the director."' Deans, "knowing less about library activities, may have a better understanding of overall effectiveness or may be influenced more by symbolic outcomes. ${ }^{\prime 20}$

Using Mintzberg's managerial model, Michael Ann Moskowitz found academic library directors involved primarily with their internal managerial roles. ${ }^{21}$ Moskowitz found university directors considerably more active than college directors in the external roles of liaison and monitor, and directors at public institutions more active than directors at private institutions in the internal role of disturbance handler. ${ }^{22}$

\section{THE STUDY}

Using a much larger population, the present descriptive study replicates and builds upon Moskowitz's work by further exploring the influence of the organization on library directors' managerial roles. This study profiles the managerial characteristics of academic library directors within the Midwest (Ohio, Kentucky, Indiana, Iowa, Illinois, Michigan, Minnesota, Wisconsin, and Missouri). The population for this study consists of all library directors in the Midwest at accredited (North Central Association of Colleges and Schools, Southern Association of Colleges and Schools) institutions with student enrollments over 500 . Institutions were identified using The HEP 1988 Higher Education Directory. In April 1989, ques- tionnaires were sent to 491 library directors. Directorships known to be vacant were excluded from the population. Usable responses were received from 354 directors, for a 70 percent return.

The chi-square, Pearson productmoment correlation coefficient, and an analysis of variance from the SAS statistical package were used to analyze the data. The analysis of variance considered the unbalanced number of observations. The level of significance for this study is .05 .

\section{INSTITUTIONAL AND INDIVIDUAL CHARACTERISTICS}

The academic institutions in the present study are grouped according to the Institutional Classification of the American Association of University Professors: Doctoral (I), Comprehensive (IIA), Baccalaureate (IIB), and Two-year Institutions with Academic Rank (III) (community colleges). ${ }^{23}$ While respondents are evenly mixed between public and private institutions, there is a heavy concentration of baccalaureate and community college directors (see table 1). Twenty-two percent of the respondents are doctoral and comprehensive university directors. Given their small numbers within the survey population, directors at doctoral institutions comprise only $4.5 \%$ of the respondents. Their low representation limits this study's ability to profile and generalize accurately about doctoral directors.

The directors are highly experienced, with a median of twenty years' experience in several different library positions (see table 1). While $40 \%$ of the directors are women, $90 \%$ of the women directors are found in baccalaureate and community colleges. Of the women directors, $38.4 \%$ were appointed from within the library to their present positions compared with $26 \%$ of the men directors. These findings collaborate earlier findings that the larger the library, the less likely it is to be directed by a woman and that women are more likely than men to be appointed director through internal promotion. ${ }^{24}$

Ninety percent of the directors hold an M.L.S., $28.3 \%$ hold an additional subject master's. Six percent of the directors, pri- 
TABLE 1

CHARACTERISTICS OF DIRECTORS

\begin{tabular}{|c|c|c|c|c|}
\hline $\begin{array}{l}\text { Characteristics } \\
\text { Public/Private }\end{array}$ & $\begin{array}{c}\text { Doctoral } \\
(\mathrm{n}=16) \\
9 / 7\end{array}$ & $\begin{array}{c}\text { Comprehensive } \\
(\mathrm{n}=62) \\
43 / 19\end{array}$ & $\begin{array}{c}\text { Baccalaureate } \\
(\mathrm{n}=146) \\
9 / 137\end{array}$ & $\begin{array}{c}\text { Community } \\
(\mathrm{n}=130) \\
116 / 14\end{array}$ \\
\hline \multicolumn{5}{|l|}{ Gender } \\
\hline Male & 12 & 43 & 81 & 52 \\
\hline Female & 4 & 19 & 65 & 76 \\
\hline \multicolumn{5}{|l|}{ Age } \\
\hline Mean & 49.6 & 49.9 & 49.6 & 46.5 \\
\hline Median & 51.0 & 50.5 & 50.0 & 45.0 \\
\hline \multicolumn{5}{|c|}{ Years of library experience } \\
\hline Mean & 22.2 & 22.7 & 20.3 & 18.5 \\
\hline Median & 21.5 & 22.5 & 20.0 & 17.0 \\
\hline \multicolumn{5}{|l|}{$\begin{array}{l}\text { Years of administrative } \\
\text { experience }\end{array}$} \\
\hline $\begin{array}{l}\text { experience } \\
\text { Mean }\end{array}$ & 17.8 & 17.7 & 15.3 & \\
\hline Median & 14.5 & 18.0 & $\begin{array}{l}15.3 \\
14.0\end{array}$ & $\begin{array}{l}10.2 \\
11.0\end{array}$ \\
\hline \multicolumn{5}{|c|}{ Tenure in present position } \\
\hline Mean & 7.8 & 8.4 & 10.1 & 10.3 \\
\hline & 7.5 & 6.0 & 7.5 & 9.0 \\
\hline \multicolumn{5}{|c|}{$\begin{array}{l}\text { Number of different library } \\
\text { positions held }\end{array}$} \\
\hline Mean & & & & \\
\hline Median & 6.0 & 5.0 & 3.0 & 3.0 \\
\hline Has Assistant Director & $87.5 \%$ & $41.9 \%$ & $30.8 \%$ & $19.2 \%$ \\
\hline
\end{tabular}

marily in community colleges, hold subject doctorates or master's without an M.L.S. Specialist certificates are held by $2.5 \%$ of the directors. Library science doctorates are held by $6.5 \%$ of the directors. Seven percent of the directors hold a subject doctorate in addition to their M.L.S. Another three percent of the directors are pursuing doctoral studies. The credential threshold for library directors in certain types of institutions may be rising. While only $17 \%$ of private baccalaureate directors hold doctorates, $26 \%$ of private comprehensive and $42 \%$ of public comprehensive directors hold doctorates.

When they entered the profession, only $46.7 \%$ of the directors aspired to be library directors. Only $35.6 \%$ of the women, compared with $56.1 \%$ of the men, aspired to be library directors. However, once they became directors, $78.1 \%$ of the women and $79.6 \%$ of the men would choose to be directors again, if they could start their careers over. These findings support earlier assertions that women librarians are generally unaware of their managerial potential and that their managerial skills exceed their own expectations. ${ }^{25}$

Directors are very satisfied with their jobs. On a scale of 1 to 5 (dislike it very much to like very much), women (4.4) and men (4.3) directors report similar mean scores. Only $7.1 \%$ of the directors $(8 \%$ of the men and $6.1 \%$ of the women) dislike their job. Sometimes, it is not the job but the environment that causes the dissatisfaction. "I like library administration but changes in the college administration have taken the luster off," writes one director. Another director indicates, "I have not always disliked the job. My present attitude is the result of mild burnout and recent changes in the working environment, changes which have produced discomfort on a far broader institutional level than the library."

\section{MANAGERIAL PROFILE}

Defining roles as an organized set of behaviors belonging to particular managers because of their position in the organizational hierarchy, Mintzberg identified ten managerial roles that all managers perform. ${ }^{26}$ These ten roles can be divided into three groups: interpersonal roles-those concerned primarily with interpersonal relationships (figurehead, liaison, leader); informational roles-those dealing primarily with the transfer of information (monitor, disseminator, spokesperson); 
and decisional roles-those that essentially involve decision making (entrepreneur, disturbance handler, resource allocator, negotiator). Distinctions are also made between a manager's internal and external roles. A manager's internal roles insure that the organization operates smoothly as a single unit. A manager's external roles involve the organization's relationship to its environment. ${ }^{27}$

The present study uses Moskowitz's phrasing of Mintzberg's role definitions to make them relevant to library directors. ${ }^{28}$ The external roles of academic library directors are defined as follows:

1. Figurehead-carrying out duties of a ceremonial nature, such as presenting and explaining the library to others

2. Liaison-maintaining contacts outside the library with college administrators and faculty

3. Monitor-receiving information outside the library through professional associations and activities and through verbal communication with colleagues

4. Spokesperson-distributing information to people outside the library and informing outsiders of progress within the system

5. Negotiator-negotiating with organizations or individuals outside the library to secure funding and safeguard interests.
The internal roles of academic library directors are defined as follows:

1. Leader-supervise subordinates' work, including placement, training, motivation, and evaluation of employees

2. Disseminator-sharing and distributing information within the library through staff meetings and personal contacts

3. Entrepreneur-introducing change within the library by developing and implementing new systems and programs

4. Disturbance Handler-handling conflicts and crises within the library and taking corrective actions when unexpected disturbances occur

5. Resource Allocator-allocating funds, time, staff, materials, and equipment to specific tasks within the library.

Directors spend more time and effort on their internal managerial roles (see table 2). When the top two categories of time and effort spent ("much" and "most") are compared with the bottom two categories ("least" and "little") the results are clear. Almost $45 \%$ of the directors spent "much and most" of their time on internal roles compared with $22 \%$ who spent "much and most" of their time and effort on external roles. Internal roles require the "least and little" time and effort of only $17 \%$ of the directors, while external roles received the

TABLE 2

EXTERNAL AND INTERNAL MANAGERIAL ROLES

\begin{tabular}{lcccccc}
\hline \hline & $\begin{array}{c}\text { Least } \\
\text { Role }\end{array}$ & $\begin{array}{c}\text { Time and Effort (Frequency)* } \\
\text { Little } \\
(1)\end{array}$ & $\begin{array}{c}\text { Moderate } \\
(3)\end{array}$ & $\begin{array}{c}\text { Much } \\
(4)\end{array}$ & $\begin{array}{c}\text { Most } \\
(5)\end{array}$ & Mean \\
\hline External & & & & & & \\
$\quad$ Figurehead & 104 & 134 & 96 & 16 & 0 & 2.1 \\
Liaison & 7 & 33 & 150 & 131 & 30 & 3.4 \\
Monitor & 12 & 94 & 168 & 72 & 6 & 2.9 \\
Spokesperson & 38 & 108 & 145 & 52 & 9 & 2.6 \\
Negotiator & 90 & 96 & 91 & 62 & 13 & 2.4 \\
$\quad$ Total & 251 & 465 & 650 & 333 & 58 & 2.7 \\
$\quad$ Percentage & 14.3 & 26.5 & 37.0 & 18.9 & 3.3 & \\
Internal & 11 & 55 & 169 & 95 & 20 & 3.1 \\
Leader & 11 & 37 & 155 & 116 & 33 & 3.3 \\
Disseminator & 2 & 24 & 112 & 150 & 63 & 3.7 \\
Entrepreneur & 36 & 86 & 119 & 83 & 28 & 2.9 \\
Disturbance handler & 3 & 40 & 111 & 128 & 70 & 3.6 \\
Resource allocator & 63 & 242 & 666 & 572 & 214 & 3.4 \\
Total & 3.6 & 13.8 & 37.9 & 32.5 & 12.2 & \\
$\quad$ Percentage & & & & & & \\
\hline
\end{tabular}

The Chi Square value of 335.68 (4 df at a P value of .001) was statistically significant.

*Directors rated their involvement with each of the ten managerial roles on a five-point scale: (1) least time and effort; (2) little time and effort; (3) moderate time and effort; (4) much time and effort; and (5) most time and effort. 
"least and little" time and effort of almost $41 \%$ of the directors. The role patterns of academic library directors in this study are very similar to those found by Moskowitz. ${ }^{29}$

There are no significant differences in the roles that men and women directors emphasize. There is also no significant correlation between years of administrative experience, years in present position, number of different positions held, and directors' internal or external managerial role scores.

\section{VARIATIONS IN A DIRECTOR'S MANAGERIAL PROFILE}

All managers perform the same roles, but individual managers emphasize different roles depending on environmental variables (e.g., age, size of the organization, nature of the organizational enterprise, mission, and culture), job variables (level in the organization and functions supervised), person variables (manager's personality and style), and situational variables (periodic patterns, cycles, and changes in the job over time). The job's organizational level and the functions supervised account for most of the variation in a manager's work. The lower the organizational level, the more informal the job and the less time spent in the figurehead role. Lower-level managers are more directly oriented towards maintaining a steady workflow; hence, they spend more time in real-time roles-disturbance handler, and negotiator. Managers in service organizations, like libraries, spend more time in the liaison role than managers in other types of organizations. ${ }^{30}$

When the directors' managerial profile is analyzed by institutional type, an analysis of variance yields some significant differences in directors' roles of monitor, negotiator, disturbance handler, and resource allocator (see table 3 ). While Moskowitz found university directors considerably more active (than are college directors) with their two external roles of liaison and monitor, the present study finds comprehensive university directors perform the role of monitor significantly more than community college directors. ${ }^{31}$
Comprehensive directors perform the role of negotiator significantly more than baccalaureate and community college directors. Comprehensive directors also perform the role of disturbance handler significantly more than other directors. Directors at doctoral institutions perform the role of resource allocator significantly less than other directors. Comprehensive directors spend significantly more time on their internal roles than do doctoral directors, but they spend significantly more time on their external roles than do baccalaureate and community college directors (see table 3).

"As managers move further from the day-to-day operations, technical skill becomes less important, provided managers have skilled subordinates and can help them solve their own problems."

While Moskowitz found directors at public institutions more active as disturbance handlers than directors at private institutions, ${ }^{32}$ the present study finds directors at public institutions significantly more active as entrepreneurs than directors at private institutions. However, within specific types of institutions (doctoral, comprehensive, baccalaureate, and community), no significant differences are found between the entrepreneur roles of public and private directors.

Earlier studies examined the internal and external emphasis of library directors, but it is also important to examine the director's managerial roles according to Mintzberg's clusters of interpersonal, informational, and decisional roles. By grouping individual roles together, regardless of their internal or external emphasis, it is possible to develop a better profile of directors in different types of institutions.

There is no real difference in the emphasis directors give their interpersonal roles (figurehead, leader and liaison) (see table 4). However, when it comes to receiving and transmitting information, comprehensive directors spend significantly 
TABLE 3

MANAGERIAL ROLES BY INSTITUTIONAL TYPE

\begin{tabular}{|c|c|c|c|c|c|c|c|c|}
\hline \multirow[b]{2}{*}{ Role } & \multicolumn{2}{|c|}{$\begin{array}{l}\text { Doctoral } \\
(\mathrm{n}=16)\end{array}$} & \multicolumn{2}{|c|}{$\begin{array}{c}\text { Comprehensive } \\
(\mathrm{n}=62)\end{array}$} & \multicolumn{2}{|c|}{$\begin{array}{l}\text { Baccalaureate } \\
(\mathrm{n}=146)\end{array}$} & \multicolumn{2}{|c|}{$\begin{array}{l}\text { Community } \\
(\mathrm{n}=130)\end{array}$} \\
\hline & $\mathrm{M}$ & SD & & & & & & \\
\hline \multicolumn{9}{|l|}{ External } \\
\hline Figurehead & 2.13 & .81 & 2.05 & .84 & 1.96 & .84 & 2.20 & .91 \\
\hline Liaison & 3.13 & .89 & 3.56 & .76 & 3.46 & .87 & 3.31 & .85 \\
\hline Monitor & 3.13 & .62 & 3.13 & $.82^{*}$ & 2.93 & .81 & 2.73 & $.82 t$ \\
\hline Spokesperson & 2.81 & .91 & 2.92 & .98 & 2.62 & .92 & 2.61 & .94 \\
\hline Negotiator & 3.00 & 1.10 & 2.89 & $1.22^{*}$ & 2.34 & $1.10 t$ & 2.34 & $1.15 t$ \\
\hline Total & 14.19 & 2.46 & 14.55 & $2.95^{*}$ & 13.03 & $3.00 t$ & 12.94 & $3.29+$ \\
\hline \multicolumn{9}{|l|}{ Internal } \\
\hline Leader & 2.75 & .93 & 3.05 & .76 & 3.19 & .91 & 3.25 & \\
\hline Disseminator & 3.31 & 1.08 & 3.52 & .88 & 3.38 & .90 & 3.24 & .89 \\
\hline Entrepreneur & 3.56 & .96 & 3.79 & .96 & 3.64 & .76 & 3.76 & .91 \\
\hline Disturbance handler & 2.50 & $.97 t$ & 3.35 & $1.10^{*}$ & 2.84 & $1.09+$ & 2.92 & $1.08 \mathrm{t}$ \\
\hline Resource allocator & 2.81 & $.75 t$ & 3.61 & $1.03^{*}$ & 3.70 & $.93^{*}$ & 3.66 & $.93^{*}$ \\
\hline Total & 14.94 & $2.49 t$ & 17.32 & $2.86^{*}$ & 16.73 & 2.73 & 16.52 & 3.59 \\
\hline
\end{tabular}

* + Refers to comparisons within a row where the mean scores of group * are significantly $(\mathrm{p} \leq .05)$ higher than the mean scores of group t.

TABLE 4

MANAGERIAL ROLE GROUPINGS BY INSTITUTIONAL TYPE

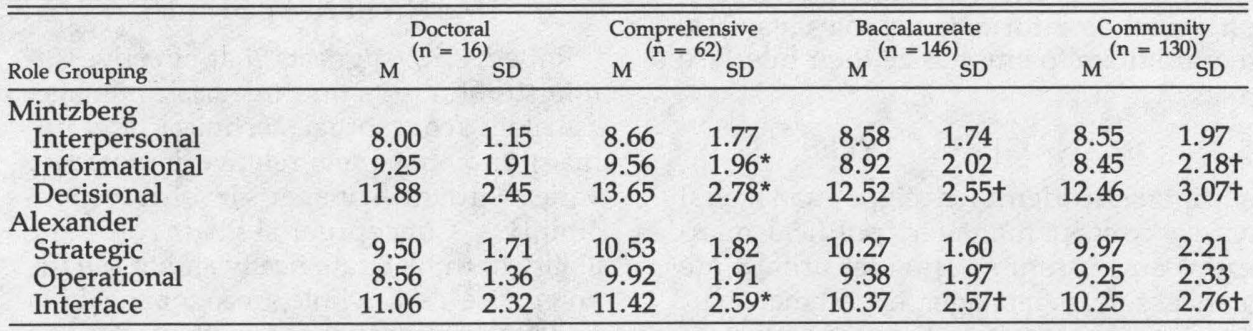

*+Refers to comparisons within a row where the mean scores of group * are significantly $(p \leq .05)$ higher than the mean scores of group $t$.

more time and effort in informational roles (monitor, disseminator, and spokesperson) than do community college directors. This emphasis on informational roles is a function of the separate administrative culture found at larger complex academic institutions. As a result of institutional size, increased administrative accountability, and the specialization of administrative tasks, administrators feel isolated and "must spend time building channels of communication and support." ${ }^{\prime 33}$ Managers' most crucial roles are their decisional roles (entrepreneur, disturbance handler, resource allocator, and negotiator). ${ }^{34}$ Among directors, comprehensive directors exercise their decisional roles significantly more than do baccalaureate and community college directors.
According to Larry Alexander, Mintzberg's ten roles can also be divided into four other role groups: strategic management, operational management, external interface, and internal interface. ${ }^{35}$ Strategic management roles (monitor, entrepreneur, and resource allocator) link the organization with its environment, determine basic goals and policies, identify growth opportunities, and allocate resources. Strategic management roles have broad implications for the organization and are primarily associated with top management. Operational management roles (leader, disseminator, and disturbance handler) involve the day-to-day directing of functional areas, resolving unexpected problems, disseminating needed information, and administrating ongoing pro- 
grams and policies. Operational management roles, concerning the day-to-day operations, are primarily associated with middle- and lower-level managers. Interface roles (figurehead, liaison, negotiator, and spokesman) are divided into external relationships outside the organization and internal relationships within the organization. ${ }^{36}$ For the present study, external and internal interface roles are combined.

Directors rank Alexander's managerial role groupings in the same order (see table 4). There is no significant difference in the emphasis directors give their strategic and operational management roles. However, when it comes to external and internal relations, comprehensive directors spend significantly more time and effort on their interface roles than do baccalaureate and community college directors. The same structural and environmental forces that require comprehensive directors to emphasize their informational roles may also require them to emphasize their interface roles.

\section{MANAGERIAL TYPES}

Mintzberg identified eight managerial types: contact manager, political manager, entrepreneur, insider, real-time manager, team manager, expert manager, and new manager. ${ }^{37}$ In the present study, 72 percent of the academic library directors indicate a preference for a managerial type. Almost 80 percent of the directors' managerial types are of an internal nature. Excluding the new manager and entrepreneur as transitional managerial types, directors at all institutions cluster in the insider, real-time, and team manager categories.

Insiders (resource allocator) are concerned with maintaining smooth-running internal operations. They spend their time building a structure, developing and training subordinates, and overseeing operations. Real-time managers (disturbance handler) are similar to insiders, devoting their efforts to ensuring that the organization's daily work continues without interruption. These managers always appear exceedingly busy and are prepared to do any job themselves. Real-time managers are usually found in one-manager organizations, organizations faced with severe crisis, and in any organization in a dynamic, competitive, high-pressure environment. Team managers (leader) are insiders preoccupied with creation of a team that operates as a cohesive whole and functions effectively. Team managers are found where organizational tasks require difficult coordination among experts. ${ }^{38}$

New managers (liaison, monitor) lacking contacts and information, seek information and a network of contacts. Their decisional roles cannot become fully operative until they have more information. Once they have the required background, new managers stress their entrepreneurial role while they attempt to put their distinct mark on their organization before they settle down into one of the other managerial types. ${ }^{39}$

\section{MANAGERIAL SKILLS}

Robert Katz suggests that effective administration rests on three basic managerial skills (conceptual, technical, and human) and that their relative importance varies with the manager's level of responsibility. ${ }^{40}$ Conceptual skills involve the ability to think strategically and to see the enterprise as a whole, recognizing how various organizational functions depend on one another, and how changes in any one part affect all others. It also extends to visualizing the organization's relationship to the larger community and external forces. Recognizing these relationships and perceiving the significant elements in any situation, managers should act in ways that advance the overall welfare of the total organization. Because an organization's overall success depends on its manager's conceptual skill in establishing, carrying out, and coordinating policy decisions, conceptual skill is of undeniable importance..$^{41}$

Technical skills involve specialized knowledge, analytical ability, and facility in the use of the discipline's tools and techniques. They are indispensable to efficient operation. Yet as managers move further from the day-to-day operations, technical skill becomes less important, provided managers have skilled subordi- 
nates and can help them solve their own problems. At the top, technical skill may be almost nonexistent, and managers may still perform effectively if their human and conceptual skills are highly developed. ${ }^{42}$

Human skills-the ability to work with others effectively and to build cooperative effort-are essential to effective management at every level. These skills are demonstrated in the way managers perceive (and recognize the perceptions of) their superiors, equals, and subordinates, and in the way they behave subsequently. Human skills are most important at lower levels, where the direct contacts between managers and subordinates are greatest. Higher up the organizational ladder, personal contacts decrease, and the need for human skills becomes proportionately, although probably not absolutely, less. Simultaneously, conceptual skills become increasingly more important with the need for policy decisions and broad-scale action. Human skills of dealing with people then become subordinate to the conceptual skills of integrating group interests and activities. ${ }^{43}$

To Katz's three basic managerial skills (conceptual, technical, and human), Cynthia M. Pavett and Alan W. Lau add political skills. ${ }^{44}$ Political skills allow managers to reconcile complex political forces acting on the organization, to negotiate during periods of conflict and bureaucratic infighting, and to form coalitions.

Directors in this study rated the importance of conceptual, technical, human, and political skills to their job on a scale of 1 to 5 (least important to most important) (see table 5). While other managers indicate conceptual skills are required to a greater extent at the highest administrative level, human skills (listening, verbal communication, patience, understanding, and written communication) are rated as most important for successful job performance. ${ }^{45}$ Academic library directors rank human skills as very important. Baccalaureate and community college directors rank human skills first followed closely by conceptual skills, while doctoral and comprehensive directors give human and conceptual skills identical top scores. All directors rank political skills more important to their jobs than technical skills.

While directors rank the four skills in basically the same order, an analysis of variance yields some significant differences among directors at different institutions (see table 5). Comprehensive directors give conceptual skills a significantly higher rating than do community college directors. Comprehensive directors also give political skills a significantly higher rating than do baccalaureate and community college directors.

Directors rate the importance of technical skills very differently. Baccalaureate directors rate technical skills significantly higher than do doctoral directors, while community college directors rate technical skills significantly higher than do comprehensive directors. Directors with assistant directors rate technical skills significantly lower than do directors without assistant directors. Directors at private institutions rate technical skills significantly higher than do directors at public institutions. However, within specific types of institutions (doctoral, comprehensive, baccalaureate, and community), no significant differences are found between public and

TABLE 5

MANAGERIAL SKILLS BY INSTITUTIONAL TYPE

\begin{tabular}{|c|c|c|c|c|c|c|c|c|}
\hline \multirow[b]{2}{*}{ Skill } & \multicolumn{2}{|c|}{$\begin{array}{l}\text { Doctoral } \\
(n=16)\end{array}$} & \multicolumn{2}{|c|}{$\begin{array}{c}\text { Comprehensive } \\
(n=62)\end{array}$} & \multicolumn{2}{|c|}{$\begin{array}{l}\text { Baccalaureate } \\
(\mathrm{n}=146)\end{array}$} & \multicolumn{2}{|c|}{$\begin{array}{c}\text { Community } \\
(n=130)\end{array}$} \\
\hline & $\mathrm{M}$ & $\mathrm{SD}$ & $\mathrm{M}$ & $\mathrm{SD}$ & $\mathrm{M}^{\prime 2}$ & SD & $\mathrm{M}^{\prime 2}$ & SD \\
\hline Human & 4.75 & .45 & 4.73 & .58 & 4.63 & .61 & 4.52 & $.69+$ \\
\hline Conceptual & 4.75 & .45 & 4.73 & $.48^{*}$ & 4.51 & .71 & 4.45 & $.72 t$ \\
\hline Political & 4.31 & .87 & 4.47 & $.76^{*}$ & 4.05 & $.88 t$ & 3.80 & $1.00 t$ \\
\hline Technical & 3.13 & $.72+\S$ & 3.47 & $.78 t$ & 3.93 & $.78^{*}$ & 3.78 & $.93 \ddagger$ \\
\hline
\end{tabular}

${ }^{*}+$ Refers to comparisons within a row where the mean scores of group * are significantly $(\mathrm{P} \leq .05)$ higher than the mean scores of group $t$.

$\ddagger \S$ Refers to comparisons within a row where the mean scores of grcup $\ddagger$ are significantly $(p \leq .05)$ higher than the mean scores of group \&. 
private directors' ratings of technical skills.

\section{WORK-CONTACT TIME}

Directors at public institutions spend significantly more time with campus administrators other than their supervisors than do directors at private institutions. However, no significant differences exist between public and private directors within specific types of institutions (doctoral, comprehensive, baccalaureate, and community). An analysis of variance indicates some significant differences in the way directors at different types of institutions spend their time (see table 6). Comprehensive directors spend significantly more time with campus administrators other than their supervisors than do baccalaureate directors. Baccalaureate and community college directors spend significantly more time with faculty than do doctoral directors.

An indication of the directors' internal orientation is the amount of time they spend with their staffs and students. It seems the larger the institution the more time directors spend with their staff and the less time they spend with students (see table 6). Community college directors with smaller staffs spend significantly less time with their staffs and significantly more time with students (other than student assistants) than do other directors. Emphasizing undergraduate education, baccalaureate directors spend signifi- cantly more time with students than do doctoral or comprehensive directors. Directors without assistant directors spend significantly more time with students than do directors with assistants.

The directors' internal orientation is similar to that found by Moskowitz where $77 \%$ of the directors spent less than $10 \%$ of their time with their supervisors and $62 \%$ of the directors spent less than $10 \%$ of their time with other administrators. Moskowitz's directors also spent more time with faculty than with administrators. $^{46}$

\section{DATA SUMMARY}

While academic library directors share many managerial commonalities, there are some important distinctions. Academic library directors in the present study are clearly more involved with their internal managerial roles. These findings corroborate similar findings by Metz and Moskowitz. ${ }^{47}$ However, there are significant differences in the managerial profiles of academic library directors. Profile differences can be accounted for by differences in the type of institution with which the library is affiliated. Variables such as the director's gender and the organization's sponsorship (public or private) have no significant influence on the director's managerial profile. While Metz and Moskowitz found differences between directors at public and private institutions, the present study suggests that differ-

TABLE 6

WORK CONTACT TIME BY INSTITUTIONAL TYPE (PERCENTAGES)

\begin{tabular}{|c|c|c|c|c|c|c|c|c|}
\hline \multirow[b]{2}{*}{ Contact } & \multicolumn{2}{|c|}{$\begin{array}{l}\text { Doctoral } \\
(\mathrm{n}=16)\end{array}$} & \multicolumn{2}{|c|}{$\begin{array}{l}\text { Comprehensive } \\
(\mathrm{n}=62)\end{array}$} & \multicolumn{2}{|c|}{$\begin{array}{l}\text { Baccalaureate } \\
M^{(n=146)} \text { SD }\end{array}$} & \multicolumn{2}{|c|}{$\begin{array}{l}\text { Community } \\
(\mathrm{n}=130)\end{array}$} \\
\hline & M & SD & $\mathrm{M}$ & & & SD & $\mathrm{M}$ & \\
\hline $\begin{array}{l}\text { Supervisor } \\
\text { Other institution }\end{array}$ & 6.44 & 4.12 & 8.32 & 5.52 & 6.39 & 6.40 & 7.93 & 7.03 \\
\hline Administrators & 7.56 & 5.62 & 9.38 & $6.56^{*}$ & 6.03 & $6.89+$ & 8.06 & 7.06 \\
\hline Faculty & 7.75 & $5.05+$ & 13.02 & 8.23 & 13.92 & $8.04^{*}$ & 14.96 & $8.02^{\star}$ \\
\hline Library staff & 57.63 & $17.79^{*}$ & 45.18 & $18.17 \ddagger$ & 42.05 & $17.95 t^{\circ}$ & 35.92 & $17.10 t, \S$,\# \\
\hline $\begin{array}{l}\text { Students (excluding } \\
\text { student employees) }\end{array}$ & 3.07 & $1.71+\S$ & 5.89 & $5.90+\S$ & 15.63 & $12.40+t$ & 22.58 & $16.37^{*}$ \\
\hline Colleagues & 8.19 & 5.31 & 9.07 & 7.37 & 7.19 & 6.32 & 6.99 & 5.56 \\
\hline Other & 8.56 & 10.15 & 20.28 & 22.59 & 21.08 & 22.76 & 18.44 & 21.96 \\
\hline
\end{tabular}

* + Refers to comparisons within a row where the mean scores of group * are significantly $(\mathrm{P} \leq .05)$ higher than the mean scores of group t.

$\ddagger \S$ Refers to comparisons within a row where the mean scores of group $\ddagger$ are significantly $(\mathrm{p} \leq .05)$ higher than the mean scores of group $\$$.

${ }^{\circ}$ \#Refers to comparisons within a row where the mean scores of group ${ }^{\circ}$ are significantly $(\mathrm{p} \leq .05)$ higher than the mean scores of group \#. 
ences between directors at public and private institutions are more the result of institutional type (doctoral, comprehensive, baccalaureate, and community) than the result of institutional sponsorship (public or private). The present study and others suggest that generalizations about differences between public and private sector managers are frequently overstated. ${ }^{48}$

There are marked differences between directors at larger comprehensive and doctoral universities and directors at smaller baccalaureate and community colleges. There are also differences within the separate college and university groupings. The present study's small number of doctoral directors limits the ability to profile them clearly. However, the individual characteristics and career patterns of doctoral directors are similar to those of comprehensive directors. Because they delegate certain operational functions to assistants, doctoral directors spend less time on internal roles, particularly those of disturbance handler and resource allocator, than do comprehensive directors.

Most comprehensive directors, facing many of the same institutional demands as doctoral directors, have no assistant directors to share their managerial roles. Comprehensive institutions not only have missions of graduate education, research, and public service, but are also expected to teach large numbers of undergraduates. This dilemma means that limited institutional resources must be spread among these competing demands to satisfy several different constituencies. Frequently, an institution's compartmentalized bureaucratic structure (both inside and outside the library) and collective bargaining units intrude upon the "collegial" environment to complicate a director's work. The result is perhaps the most complex managerial role profile. While more internally oriented than doctoral directors, comprehensive directors are more active as disturbance handlers than any of the directors. Comprehensive directors are more active with their external roles, particularly those of monitor and negotiator, than baccalaureate and community college directors. With several diverse constituencies comprehensive directors rate political skills as being more important to their job than do baccalaureate and community college directors.

\section{"Variables such as the director's gen- der and the organization's sponsor- ship have no significant influence on the director's managerial profile."}

Because of similarities in their smaller size and more focused institutional missions, baccalaureate and community college directors share more in common as managers than doctoral and comprehensive directors. Less externally oriented than comprehensive directors, baccalaureate and community college directors spend more time with faculty and students, spend less time as negotiators and decision makers, and see technical skills more important to their jobs than do other directors. Perhaps their situations demand and their constituencies expect these directors to "tend to the library" and perform more as professional librarians than as managers.

\section{DISCUSSION}

The managerial profiles identified in the present study are the result of complex interactions among individual library directors, their libraries, academic institutions, and external environments. The extent to which organizations and their environments influence managers, or managers influence their organizations and environments, is a subject of considerable debate. Mintzberg believes managerial effectiveness is significantly influenced by managers' insight into their work. He also contends that managers influence their organizations through the emphasis they place on individual roles and that preference for a particular role determines managers' choice of management strategies. ${ }^{49}$

However, Jane Hannaway recognizes that managers' actions are conditioned by the organizational context in which they operate. ${ }^{50}$ Under conditions of uncertainty and ambiguity, managers confront a broad range of demands. Responding to 
demands, managers try to make sense of their environment and their actions. However, because the number of demands exceeds their capacity to handle them, managers focus on things selectively. What managers can do at any one time is limited. ${ }^{51}$

Managers try to do a good job for their organizations, but they also want to be well thought of, or, perhaps more importantly, not to have things reflect badly on them. However, behavior in the organization's best interest may not be in the manager's best interest. Because connections between managerial actions and outcomes are not always tightly linked, managers are not always sure what behavior benefits themselves and their organizations. Managers do, however, receive signals from a number of different constituencies about what they should do and how seriously they should attend to various aspects of their work. ${ }^{52}$

The same structure that allows managers to receive signals also allows astute managers to send signals about their organization and their own contributions. Because negative information is transmitted more frequently, objective measures of an organization's performance and a manager's contribution are not available generally. Successful managers, particularly those in complex organizations, are involved actively in managing their own reputation and that of their organization. External relations, especially those that provide organizational resources, deserve managers' serious attention. When handled well, these relations enhance man-

\section{"Because library directors, like other academic managers, tend to be reac- tive, this article describes what is, rather than what ought to be."}

agers' reputations and influence within their organizations. ${ }^{53}$

Because library directors, like other academic managers, tend to be reactive, ${ }^{54}$ this article describes what is, rather than what ought to be. By increasing academic library directors' understanding of their managerial roles and environment, they may be better able to cope with the stress and ambiguities endemic to their managerial lives. Successful managerial performance depends on managers' accurate perceptions of their position's role requirements. ${ }^{55}$

More research needs to be conducted. Managerial roles are influenced substantially by managers' hierarchical levels and the organizational areas they manage. ${ }^{56}$ The managerial profile of academic library directors needs to be compared with those of other academic managers to understand adequately the influence of the parent organization and its environment on library directors. Comparing the managerial profile of library directors with the managerial profile of other academic managers will determine if library directors' managerial profile is organizationally unique or simply a common pattern shared with other academic middle managers.

\section{REFERENCES}

1. Anne Woodsworth, "Library Directors as Middle Managers: A Neglected Resource," Library Administration and Management 3:24 (Winter 1989).

2. Edward D. Garten, "Observations on Why So Few Chief Library Officers Move into Senior Academic Administration," Library Administration and Management 2:95-98 (March 1988).

3. Ruth J. Person, "The Third Culture: Managerial Socialization in the Library Setting," in Gerard B. McCabe and Bernard Kreissman, eds. Advances in Library Administration and Organization (Greenwich, Conn.: JAI Press, 1985), p.2-3.

4. Henry Mintzberg, The Structuring of Organizations: A Synthesis of Research (Englewood Cliffs, N.J.: Prentice-Hall, 1979), p.348-79.

5. Ibid., p. $358,361$.

6. Ibid., p.362-63. 
7. Robert Birnbaum, How Colleges Work: The Cybernetics of Academic Organization and Leadership (San Francisco: Jossey-Bass, 1988), p.42.

8. Susan Lee, "Conflict and Ambiguity in the Role of the Academic Library Director," College $\mathcal{E}$ Research Libraries 38:396-403 (Sept. 1977).

9. Ibid., p.397.

10. Ibid., p.400.

11. Paul Metz, "The Role of the Academic Library Director," Journal of Academic Librarianship 5:149 (July 1979).

12. Ibid., p.151.

13. Henry Mintzberg, The Nature of Managerial Work (Englewood Cliffs, N.J.: Prentice-Hall, 1980).

14. Paul J. Pugliese, "The Nature of Managerial Work: The Extent Mintzberg's Roles Are Required by the Chief Executives in Academic and Public Libraries" (Ph.D. diss., Univ. of Pittsburgh, 1985), p.93-99.

15. Ruth J. Person, "Middle Managers in Academic and Public Libraries: Managerial Role Concepts" (Ph.D. diss., Univ. of Michigan, 1980), p.124,149-150.

16. Terrence F. Mech, "Public Library Directors: A Career and Managerial Profile," Public Libraries 28:233 (July/Aug. 1989).

17. Joanne R. Euster, The Academic Library Director: Management Activities and Effectiveness (New York: Greenwood, 1987).

18. Morgan W. McCall and Cheryl A. Segrist, In Pursuit of the Manager's Job: Building on Mintzberg (Greensboro, N.C.: Center for Creative Leadership, 1980).

19. Euster, Academic Library Director, p.66.

20. Ibid., p.68.

21. Michael Ann Moskowitz, "The Managerial Roles of Academic Library Directors: The Mintzberg Model," College \& Research Libraries 47:452-59 (Sept. 1986).

22. Ibid., p.458.

23. "The Annual Report on the Economic Status of the Profession 1988-1989" [Special issue]. ACADEME: Bulletin of the American Association of University Professors 75:20 (March-April 1989).

24. Paul Metz, "Administrative Succession in the Academic Library," College \& Research Libraries 39:361 (Sept. 1978); Barbara Moran, "Career Patterns of Academic Library Administrators," College \& Research Libraries 44:338 (Sept. 1983).

25. Peter Hiatt, "Should Professionals Be Managers?" Journal of Library Administration 4:35 (Spring 1983).

26. Mintzberg, Nature of Managerial Work, p.54-99.

27. Mintzberg, Structuring of Organizations, p. 25.

28. Moskowitz, "Managerial Roles," p.454.

29. Ibid., p.456.

30. Mintzberg, Nature of Managerial Work, p.129-30.

31. Moskowitz, "Managerial Roles," p.458.

32. Ibid., p.458.

33. David D. Dill, "The Nature of Administrative Behavior in Higher Education," Educational Administration Quarterly 20:77 (Summer 1984).

34. Mintzberg, Nature of Managerial Work, p.77.

35. Larry Alexander, "The Effect of Level in the Hierarchy and Functional Area on the Extent to Which Mintzberg's Managerial Roles Are Required by Managerial Jobs"' (Ph.D. diss., University of California, Los Angeles, 1979).

36. Ibid., p.18, 32-36.

37. Mintzberg, Nature of Managerial Work, p.126.

38. Ibid., p.128-29.

39. Ibid., p.129.

40. Robert L. Katz, "Skills of an Effective Administrator," Harvard Business Review 52:90-102 (Sept.-Oct. 1974).

41. Ibid., p.91, 93-94.

42. Ibid., p.91, 94-95.

43. Ibid., p.91, 95.

44. Cynthia M. Pavett and Alan W. Lau, "Managerial Work: The Influence of Hierarchical Level and Functional Specialty," Academy of Management Journal 26:170-77 (March 1983).

45. Ibid., p.176.

46. Moskowitz, "Managerial Roles," p.456. 
47. Metz, "Role of the Director," p.149; Moskowitz, "Managerial Roles," p.458.

48. Alan W. Lau and Cynthia M. Pavett, "The Nature of Managerial Work: A Comparison of Publicand Private-Sector Managers," Group \& Organization Studies 5:453-66 (Dec. 1980); Alan W. Lau, Arthur R. Newman, and Laurie A. Broedling, "The Nature of Managerial Work in the Public Sector," Public Administration Review 40:513-20 (Sept./Oct. 1980).

49. Adeline E. Fain, "Managerial Role Perceptions of State Chief Executive Officers," Community College Review 15:5 (Winter 1987).

50. Jane Hannaway, Managers Managing: The Workings of an Administrative System (New York: Oxford Univ. Pr., 1989), p.134, 141.

51. Ibid., p.142.

52. Ibid., p.142-43.

53. Ibid., p.143-45.

54. Dill, "Nature of Administrative Behavior," p.75-76.

55. Lyman W. Porter and Edward E. Lawler III, Managerial Attitudes and Performance (Homewood, Ill: Dorsey Press, 1968), p.114.

56. Joseph G. P. Paolillo, "Managers' Self Assessments of Managerial Roles: The Influence of Hierarchical Level," Journal of Management 17:43-54 (Spring 1981); Joseph G. P. Paolillo, "Role Profiles for Managers in Different Functional Areas," Group E Organization Studies 12:109-18 (March 1987).

\section{IN FORTHCOMING ISSUES OF COLLEGE \& RESEARCH LIBRARIES}

Academic Libraries and Affirmative Action: Approaching Cultural Diversity in 1990s by Cliff Glaviano and R. Errol Lam

The Two-year College Learning Resource Center: Promise Deferred?

by Esther Green Bierbaum

Elements of the Bibliographic Record Used by Reference Staff Members

by Jon R. Hufford

Here Today... Gone Tomorrow: A pH Investigation of BYU 1987 Library Acq.

by Randall Butler

Ranking of Journals in Library and Information Science

by Mary Kim

Automation in College Library

by Richard Werking 


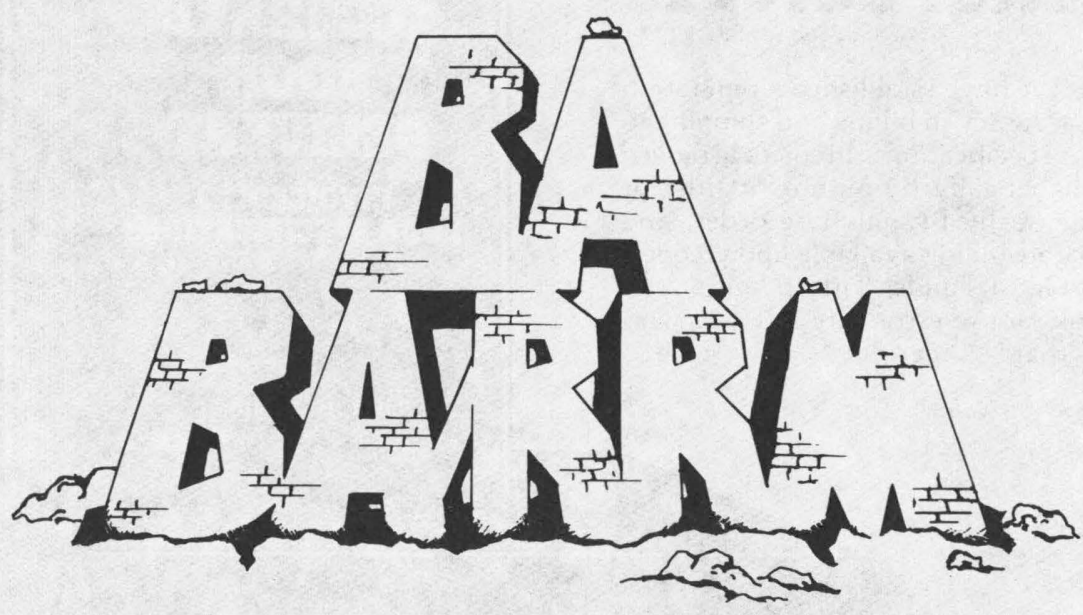

THE SOLID RESEARCH FOUNDATION.

Success in life science research depends on a solid base of knowledge. For over 60 years, BIOSIS has laid this groundwork by providing the most comprehensive life science database in the world.

Biological Abstracts ${ }^{\circledR}$ (BA), our cornerstone reference publication, helps you access the biological and biomedical literature published in more than 100 countries. In 1990 alone, BA will include 275,000 citations with abstracts!

And, to build your library of research sources beyond the journal literature, turn to Biological Abstracts $/$ RRM $^{\circledR}$ (Reports, Reviews, Meetings) (BA/RRM) for exhaustive coverage of papers from meetings and symposia, as well as books, book chapters and review publications.

Together, $\boldsymbol{B A}, \boldsymbol{B A} / \boldsymbol{R} \boldsymbol{R} \boldsymbol{M}$ and their Cumulative Indexes give you a solid research foundation - the first step toward success.

For more information contact BIOSIS, Marketing Section, Dept. CRL990SF, 2100 Arch Street, Philadelphia, PA 19103-1399 USA. Or call toll free 1-800523-4806 (USA except PA); (215) 587-4800 (worldwide); Telex 831739; Fax (215) 587-2016.

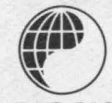

\section{BIOSIS $^{\circledR}$}

Information for Today's Decisions and Discoveries

Biological Abstracts and Biological Abstracts/RRM (Reports, Reviews, Meetings), are registered trademarks of BIOSIS.

BIOSIS is a registered trademark of Biological Abstracts, Inc. 


\section{ACQUISITION PERSPECTIVES}

4. We have established a reputation for accuracy in billing and shipping to your specifications. Invoices arranged alphabetically by author or title, or numerically by purchase order, and separate billing available upon request for Grant Funds, Title II, gifts, etc. Book House error rate last year was

less than $1 / 3$ percent.

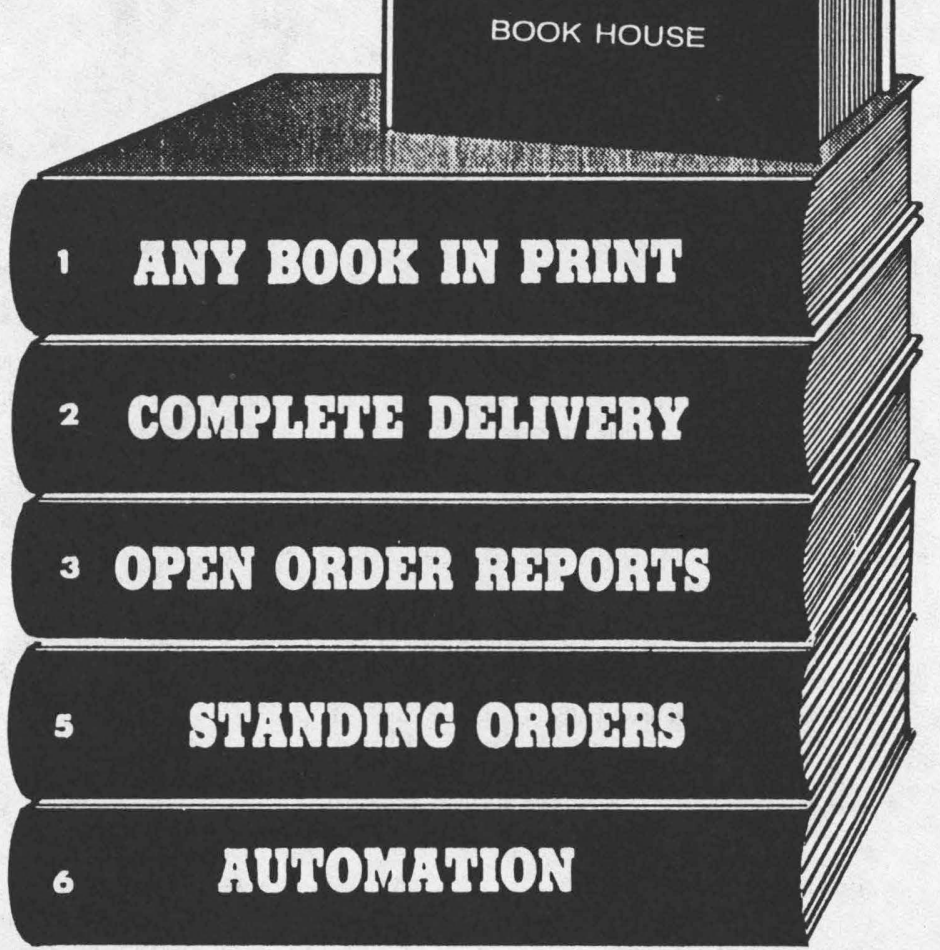

the

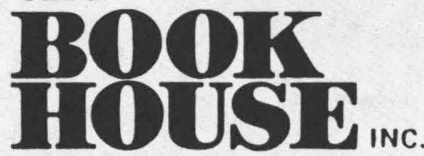

Since 1962

JOBBERS SERVING LIBRARIES WITH

ANY BOOK IN PAINT SINCE 1962

208 WEST CHICAGO STREET

JONESVILLE, MICHIGAN 492500125

ACEURTHS

$$
\text { BOOR }
$$

Dमापमा?

IVVOLE TO YOUR SPECINLCITLNS

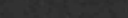

4

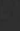
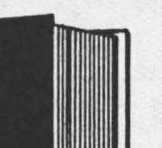

\section{is}

